\title{
Hemşirelik Öğrencilerinin Eğitimden Beklentileri ve Memnuniyet Düzeyleri
}

Nursing Students' Expectations from Education and Satisfaction Levels

\author{
Yasemin ERGÜN ${ }^{1}$, Çağla ISLATTI MUTLU ${ }^{2}$, Diler DEMIR ${ }^{3}$, Elif BERKER ${ }^{4}$, Gamze ANIK $^{5}$
}

\section{ÖZ}

$\mathrm{Bu}$ çalışma hemșirelik öğrencilerinin eğitimden beklentilerini ve memnuniyet düzeylerini belirlemek amacıyla tanımlayıcı türde yapılmıştır. Araştırma, bir devlet üniversitenin hemşirelik bölümü 2., 3. ve 4. sinıf öğrencilerinden çalışmaya katılmaya gönüllü olan 365 öğrenci ile gerçekleştirilmiştir. Verilerin toplanmasında Soru Formu ve Öğrenci Doyum ÖlçeğiKısa Formu kullanılmıştır. Verilerin analizinde tanımlayıcı istatistikler, bağımsız gruplarda $t$ testi ve ANOVA testinden yararlanılmıştır. Öğrencilerin $\% 67,7$ 'sinin teorik, \%63,3'ünün uygulamalı eğitimden memnuniyeti 5 puan ve altı değerlendirdiği belirlenmiştir. Katılımcıların doyum ölçeğinden aldikları toplam puan ortalamas1 $2,95 \pm 0,63$ olup orta düzeydedir. Öğretim elemanı alt boyutundan puan ortalaması en yüksek $(3,14 \pm 0,69)$ iken bilimsel sosyal etkinlik alt boyutundan en düşük puan ortalaması $(2,81 \pm 0,70)$ alınmıştır. Öğrencilerin sınıfları ile doyum ölçeği puan ortalaması arasında istatistiki açıdan farklılık olup eğitimin mesleki ve bireysel gelişim, öğrenmeyi teşvik etme beklentilerini karşıladığını düşünenlerin puanları yüksek bulunmuştur $(\mathrm{p}<0,05)$. Bilimsel sosyal faaliyetlerin düzenlenmesi, öğretim elemanları ile hemşirelerin paylaşıma açık, destekleyici tutum geliştirmesiyle birlikte iyi bir rol model olması, rehber hemşire sisteminin uygulanması, öğrenci odaklı kurum kültürü oluşturulması önerilmektedir.

Anahtar Kelimeler: Beklenti, Hemşirelik eğitimi, Memnuniyet, Öğrenci sorunları

\begin{abstract}
This study was carried out in a descriptive manner in order to determine the expectations of nursing students from education, their difficulties, their suggestions for dealing with these difficulties and their level of satisfaction. The study was carried out with 365 students who volunteered to participate in the study from the nursing department of a state university, 2nd, 3 rd and 4th grade students. Questionnaire and Student Satisfaction Scale-Short Form were used to collect the data. In the analysis of the data, descriptive statistics, ttest in independent groups and ANOVA test were used. It was determined that $67.7 \%$ of the students rated the satisfaction of the theoretical and $63.3 \%$ of the applied education 5 points or less. The average total score of the participants on the satisfaction scale is $2.95 \pm 0.63$ and it is at the intermediate level. While the average score from the academic staff sub-dimension was the highest $(3.14 \pm 0.69)$, the lowest average score was obtained from the scientific social activity subdimension $(2.81 \pm 0.70)$. There was a statistically significant difference between the students' classes and the average score of the satisfaction scale, and the scores of those who thought that education met the expectations of professional and individual development and encouraging learning were found to be high $(\mathrm{p}<0.05)$. It is recommended to organize scientific social activities, to be a good role model with teaching staff and nurses developing a supportive attitude open to sharing, implementing the guidance nurse system, and establishing a student oriented institutional culture.
\end{abstract}

Keywords: Expectation, Nursing education, Satisfaction, Student problems

*Bu çalı̧̧ma 18. Ulusal Hemşirelik Öğrencileri Kongresi’nde sözel bildiri olarak sunulmuştur.

${ }^{1}$ Dr. Öğr. Üyesi, Yasemin ERGÜN, Hemşirelikte Yönetim Anabilim Dalı, Marmara Üniversitesi, yaseminakbalergun@ gmail.com, ORCID: 0000$0002-4667-4313$

${ }^{2}$ Arş. Gör., Çağla ISLATTI MUTLU, Hemşirelikte Yönetim Anabilim Dalı, Marmara Üniversitesi, caglaislatti@ gmail.com, ORCID: 0000-00024689-229X

${ }^{3}$ Hemşire, Elif BERKER, John Hopkins Anadolu Sağlık Merkezi, dilerdemirr@ gmail.com, ORCID: 0000-0002-1484-7662

${ }^{4}$ Hemşire, Diler DEMIR, Edremit Devlet Hastanesi, berkerelif@ hotmail.com, ORCID: 0000-0001-5744-7039

${ }^{5}$ Hemșire, Gamze ANIK Hemşirelik Anabilim Dalı, Marmara Üniversitesi Sağlık Bilimleri Enstitüsü, gamzeanikk@ gmail.com, ORCID: 00000001-9883-991X

$\begin{array}{lll}\text { İletişim / Corresponding Author: } & \text { Çağla ISLATTI MUTLU } & \text { Geliş Tarihi / Received: } \\ \text { e-posta/e-mail: } & \text { caglaislatti@gmail.com } & \text { 04.06.2020 } \\ & & \text { Kabul Tarihi/Accepted: }\end{array}$




\section{GİRIS}

Hemşirelik mesleğinde verilen eğitim, hemşirelerin bireye, aileye ve topluma sunduğu hizmetin kalitesini önemli ölçüde etkileyecektir. $\mathrm{Bu}$ nedenle mesleğin geliştirilmesi ve güçlendirilmesinde eğitimin niteliğinin yükseltilerek kaliteli eğitimin sağlanması ön planda olmalıdır. ${ }^{-3} \mathrm{Bu}$ bağlamda, toplum gerçeklerinin ve ihtiyaçlarının dikkate alınarak hemşirelik mesleğinin ve mesleki eğitiminin geliştirilmesi, sosyokültürel gelişimini sağlamış ve donanımlı profesyonel meslek üyelerinin yetiştirilmesi hemşirelik eğitimi veren okulların temel hedefi olarak görülmelidir. ${ }^{4-6}$

Eğitim kurumları verdikleri nitelikli ve kaliteli eğitim ile yeterli bilgi ve beceriye sahip, kritik düşünme, analiz ve sentez yaparak başarısını ortaya koyabilen, etkili ve verimli çalışan hemşirelerin yetişmesine olanak sağlamaktadır. ${ }^{7,8}$ Diğer yandan kaliteli bir eğitim, öğrencinin şu anda ve gelecekte, topluma ve okuluna bağlılığını arttıracak bilimsel, psikolojik, sosyal ve ahlaki değerlerinin gelișmesine imkan tanıyacaktır. ${ }^{9}$ Üniversiteler bu amaçla hizmetlerini iyileştirmek ve geliştirmek için çeşitli girişimlerde bulunmaktadır. Girişimlerden bazıları da son yıllarda önem kazanan yüksek eğitimde kalite, akreditasyon ve memnuniyet çalışmalarıdır. Özellikle kalite iyileştirme çalışmalarında, bizzat bu hizmeti yaşayan öğrencilerin görüşlerine yer verilmesinin önemi, yadsınamaz bir gerçektir. Çünkü en gerçekçi ve en isabetli önerileri sunacak olan öğrencilerin kendisidir. Yine öğrencilerin öğrenim gördükleri programla ilgili algılarını ve beklentilerini değerlendirmek hizmetin niteliğini geliştirmek açısından önemlidir. ${ }^{10,11}$ Eğitimde tüm paydaşların ve öğrencilerin işbirliği içinde bulunması yaşanılan sorunlara ilişkin daha etkili öneriler getirilmesini sağlayarak eğitim kurumlarının başarısını arttıracaktır. $^{12,13}$ Eğitim kurumlarının etkinliklerini amaçlı, planlı ve kontrollü düzenlemesi, eğitimin kaliteli olmasını sağlarken öğrencilerin memnuniyetlerini arttırmaktadır. ${ }^{10,11,14,15}$
Memnuniyet, bir hizmetin tatmin edici şekilde yerine getirilmesi, beklentilerin, gereksinimlerin, istek ve dileklerin karşılanmasıdır. ${ }^{16}$ Öğrencilerin öğrenim gördükleri kurumlara yönelik memnuniyetleri için eğitim-öğretim hizmetlerinde fiziki mekanlar, derslikler, bilgisayar olanakları, kütüphane, barınma, güvenlik ve yemek gibi temel ihtiyaçların yanı sıra sosyal, kültürel, sportif olanaklar gibi diğer ihtiyaçlarının da değerlendirilip karşılanması gerekmektedir. ${ }^{17}$,

$18 \mathrm{Bu}$ nedenle üniversiteler, eğitim hizmetlerini tasarlarken akademik boyutu dikkate aldı $\breve{g} 1$ kadar kampüste bulunan diğer sosyal olanakları da dikkate almalıdır. ${ }^{19}$ Başka bir deyişle, sunulan hizmetler öğrencinin akademik, fiziksel, ruhsal ve sosyal deneyimlerinin bir karışımı olmalı ve beklentilerini karşılamalıdır. ${ }^{20,21}$ Beklentilerin karşılanmaması şikayetleri ve memnuniyetsizliği arttırır. Şikayetlerin azaldığ 1 oranda memnuniyet düzeyinin arttığı görülmektedir. ${ }^{22,23}$ Memnuniyetle ilişkili indikatörlerin, yüksek öğretim kurumlarının eğitim, öğretim, araştırma işlevlerinin yanında öğrencilerin sosyalleşme, toplumsal ve kültürel duyarlılık kazanma gibi konuları da içine alan geniş bir perspektife sahip olması kalite kavramını da birçok konu ile bütünleştirmektedir. $\mathrm{Bu}$ kavramın somut göstergeler olarak ölçülmesi için öğrenci görüşleri alınmalıdır. ${ }^{24}$ Öğrencilerin yaşadıkları problemleri dile getirerek bunlara yönelik çözüm önerileri sunmaları, eleştirel düşünme ve sorun çözme becerilerini geliştirmektedir. Sorun ve çözüm önerilerine üniversiteler tarafından duyarlı olunması, memnuniyet ve kalite düzeylerini arttırmada yardımcı olacaktır. ${ }^{25}$

Topluma nitelikli hizmet sunacak donanımlı profesyoneller yetiştirmek için üniversitelerin düzenli ve belli aralıklarla öğrencilerin memnuniyet düzeylerini ve beklentilerini ölçmeleri, sonuçlar doğrultusunda iyileștirme ve geliștirme uygulamasında bulunmaları gerekmektedir. ${ }^{26}$

$\mathrm{Bu}$ çalışmada hemşirelik öğrencilerinin eğitimden beklentilerinin ve memnuniyet düzeylerinin belirlenmesi amaçlanmış olup 
bu doğrultuda öğrencilerin yaşadıkları sorunlar ve çözüm önerileri de belirlenmiştir.

Çalışmada şu sorulara yanıt aranmıştır.

- Öğrencilerin memnuniyet düzeyi nedir?

- Öğrencilerin eğitimden beklentileri nelerdir?
- Öğrenciler hangi konularda sorun yaşamaktadır?

- Öğrenciler sorunlara ne tür çözümler önermişlerdir?

\section{MATERYAL VE METOT}

\section{Araştırmanın Tipi}

Tanımlayıcı türde yapılmış bir çalışmadır.

\section{Araştırmanın Evren ve Örneklemi}

Araştırmanın evrenini bir devlet üniversitesinde 2018-2019 Eğitim-Öğretim y1lı Bahar döneminde öğrenim gören Hemşirelik Bölümü 2., 3. ve 4. sınıf öğrencileri ( $N=720$ öğrenci) oluşturmaktadır. Örnekleme yöntemine gidilmeyip evrenin tamamına ulaşılması hedeflenmiş̧ir. Çalışma 20 Şubat - 05 Mart 2019 tarihleri arasında çalışmaya katılmaya gönüllü olan 365 öğrenci ile tamamlanmıştır. Evrene ulaşma oranı $\% 50,69$ 'dur. Araştırmaya kabul edilme şartları veri toplama tarihlerinde ilgili üniversitenin hemşirelik bölümü 2., 3. veya 4 . sınıfında öğrenim görmesi ve gönüllü katılım sağlaması iken dışlanma kriterleri 1. sınıf öğrencisi olması ve veri toplama araçlarını eksik veya yanlış doldurması şeklinde belirlenmiştir. Birinci sınıf öğrencileri üniversite yaşamına yeni başladıkları ve henüz adaptasyon sürecinde oldukları için araştırma kapsamına alınmamıştır.

\section{Veri Toplama Araçları}

Araştırmada veri toplama aracı olarak araştırma ekibi tarafindan ilgili literatür doğrultusunda hazırlanan Soru Formu ve Öğrenci Doyum Ölçeği-Kısa Formu kullanılmıştır.

Soru formu, araştırmaya dahil edilen sinıflardaki öğrencilerin görüşleri, araştırmacıların gözlemleri ve konuyla ilgili literatür doğrultusunda araştırmacılar tarafından hazırlanmıștır. $\mathrm{Bu}$ form öğrencilerin bireysel özelliklerine, hemşirelik mesleğine ilişkin görüşlerine, mesleki eğitim ile ilgili beklenti ve memnuniyetlerine, uygulamalı ve kuramsal eğitim, laboratuvar eğitimi, fiziki özellikler ve okul yönetimine ilişkin yaşadıkları sorunlar ve çözüm önerilerine yönelik sorulardan oluşmaktadır. Hemşirelik öğrencilerinin doyumlarını ölçmek amacıyla Baykal, Harmancı, Eşkin, Altuntaş ve Sökmen (2011) ${ }^{16}$ tarafindan geliştirilen "Öğrenci Doyum Ölçeği-Kısa Formu" kullanılmıştır. Ölçek 53 madde ve 5 faktörden oluşan beşli likert tipindedir ve negatif ifade bulunmamaktadır. Madde puanlamas "1- kesinlikle katılmıorum", "5kesinlikle katıliyorum" arasında değişmektedir. Ölçeğin faktörleri öğretim elemanları, okul yönetimi, kararlara katılım, bilimsel sosyal ve teknik olanaklar ve eğitimöğretimin niteliğidir. Cronbach alfa katsayısı ölçeğin toplamında $0,97 \mathrm{iken}$ alt boyutlarında 0,83 ile 0,91 arasında olup güvenilir bir ölçektir. Ölçek ve alt boyutlarından alınan puan ortalaması "1" e yaklaştıkça öğrenci doyumunun düşük, "5" e yaklaştıkça doyumun yüksek olduğu anlaşılmaktadır.

\section{Araştırmanın Etik Yönü}

Araştırmanın etik kurul izni (18.02.2019-73 onay tarih ve saylli) ve kurum izni (1900049947 say1lı) bulunmaktadır. Ölçek kullanımı için Sökmen'den yazılı ölçek izni alınmıştır. Çalışmaya katılan öğrenciler ile yüz yüze görüşülerek çalışma hakkında bilgi verilmiş, hiçbir bask1 altında kalmadan gönüllü olarak katılımları talep edilmiş ve onamları alınmıştır.

\section{Verilerin Değerlendirilmesi}

Veriler SPSS 20.0 paket programı ile analiz edilmiş olup verilerin değerlendirilmesinde frekans, yüzdelik, ortalama, standart sapma gibi tanımlayıc1 istatistik değerleri kullanılmıştır. Normal dağılıma uygunluğu Kolmogrov-Smirnov testi ile yapılmıştır. Normal dağılıma uyan 
değişkenlerde Bağımsız Gruplarda T Testi ve ANOVA testi kullanılmıştır. Farklılığın hangi gruptan kaynaklandığını belirlemek için ileri istatistik analizler yapılmıştır (Tukey HSD testi). Veri analizlerinde anlamlılık değeri $\mathrm{p}<0,05$ olarak kabul edilmiştir.

\section{Araştırmanın Sınırlılıkları}

Çalışma devlet üniversitenin hemşirelik bölümü 2018-2019 Eğitim-Öğretim yılı Bahar döneminde öğrenim gören 2., 3. ve 4. sinıf öğrencileri ile sınırlıdır. Tüm hemşirelik bölümü öğrencilerine genellenemez. Araştırma verileri katılımcıların öz bildirimine dayalıdır.

\section{BULGULAR VE TARTIŞMA}

Katılımcıların yaş ortalaması $20,76 \pm 1,47$, yarıdan fazlası $(\% 77,3)$ kadın ve Anadolu lisesi mezunu $(\% 67,1)$ olup \%46,6's1 2.sinif öğrencisidir. Öğrencilerin \%47,4'ünün annesi, \%38,6'sının babası ilkokul mezunu ve \%18,1'inin sağlık çalışanı olan bir yakını bulunmaktadır (Tablo 1).

Tablo 1. Öğrencilerin Tanıtıcı Özellikleri İle Bölüme ve Mesleğe İlişkin Görüsşlerin Dağılımı $(\mathbf{n}=\mathbf{3 6 5})$

\begin{tabular}{|c|c|c|}
\hline Değişkenler & $\mathbf{n}$ & $\%$ \\
\hline \multicolumn{3}{|l|}{ Cinsiyet } \\
\hline Kadın & 282 & 77,3 \\
\hline Erkek & 83 & 22,7 \\
\hline \multicolumn{3}{|l|}{ Yaş } \\
\hline 20 ve alt 1 & 175 & 47,9 \\
\hline 21 ve üstü & 190 & 52,1 \\
\hline \multicolumn{3}{|l|}{ Sinıf } \\
\hline 2.sinif & 170 & 46,6 \\
\hline 3.sinif & 116 & 31,8 \\
\hline 4.sinif & 79 & 21,6 \\
\hline \multicolumn{3}{|c|}{ Sağlık calıșanı akraba varlığı } \\
\hline Evet & 66 & 18,1 \\
\hline Hayır & 299 & 81,9 \\
\hline \multicolumn{3}{|c|}{ Bölümü isteyerek seçme } \\
\hline Evet & 178 & 48,8 \\
\hline Hayır & 187 & 51,2 \\
\hline \multicolumn{3}{|c|}{ Mesleği başkasına önerme } \\
\hline Evet & 246 & 67,4 \\
\hline Hayır & 119 & 32,6 \\
\hline \multicolumn{3}{|c|}{ Mesleği seçme nedenleri * } \\
\hline İș olanağ1 & 222 & 60,8 \\
\hline Sinav puanı & 143 & 39,2 \\
\hline İnsana hizmet etme & 83 & 22,7 \\
\hline Sağlık alanı olması & 145 & 39,7 \\
\hline Tavsiye, öneri & 39 & 10,7 \\
\hline Aile isteğ $\mathrm{i}$ & 26 & 7,1 \\
\hline
\end{tabular}

*Birden çok mesleği seçme nedeni işaretlenmiştir.

Katılımcıların yarıya yakını $(\% 48,8)$ bölüme isteyerek gelmiş ve yarıdan fazlası $(\% 67,4)$ hemşirelik mesleğini başkasına önerebileceğini belirtmiştir.
Öğrenciler \%60,8 oranla iș bulma olanağının yüksek olması nedeniyle bölümü tercih etmektedir. Diğer tercih nedenleri ise; üniversite giriş puanının ancak hemşirelik bölümüne giriş için yeterli olması $(\% 39,2)$, sağlık alanının ilgi alanı içinde olması $(\% 39,7)$, öğrencilerin insanlara yardım etmeyi sevmesi $(\% 22,7)$, mesleğin tavsiye edilmesi $(\% 10,7)$ ve aile üyelerinin hemşirelik mesleğini seçmesini istemeleridir $(\% 7,1)$ (Tablo 1).

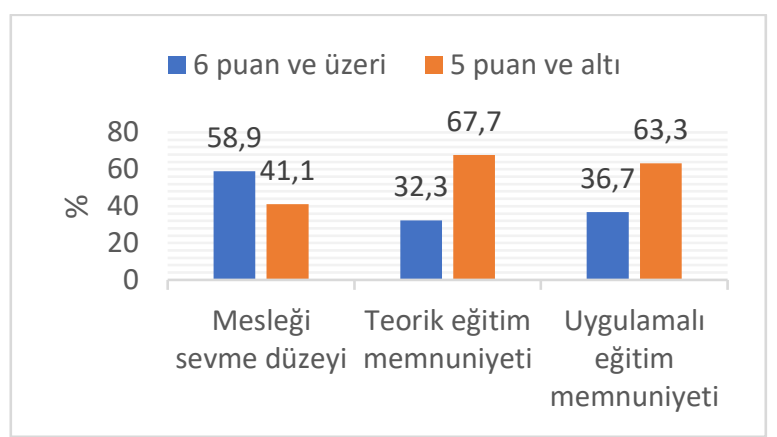

Şekil 1. Öğrencilerin Mesleği Sevme, Teorik ve Uygulamalı Eğitimden Memnuniyetlerine İlişkin Puanlandırmaları $(n=365)$

Katılımcıların hemşirelik mesleğini sevme, teorik ve uygulamalı eğitimden memnuniyet düzeylerini 10 üzerinden puanlandırmaları istendiğinde; katılımcıların \%58,9'u mesleği sevme düzeyini 6 puan ve üzeri olarak değerlendirirken, \%67,7'si teorik eğitimden memnuniyeti, \%63,3'ü uygulamalı eğitimden memnuniyeti 5 puan ve altı olarak değerlendirmiştir (Şekil 1).

Tablo 2. Öğrencilerin Doyum Ölçeği Toplam ve Alt Boyut Puan Ortalamalari

\begin{tabular}{lc}
\hline Alt boyutları & Ort. \pm SS \\
\hline Öğretim elemanı & $3,14 \pm 0,69$ \\
Okul yönetimi & $2,91 \pm 0,75$ \\
Kararlara katılım & $2,85 \pm 0,78$ \\
Bilimsel sosyal etkinlikler & $2,81 \pm 0,70$ \\
Eğitim öğretim & $3,00 \pm 0,72$ \\
\hline Toplam puan ortalaması & $2,95 \pm 0,63$ \\
\hline
\end{tabular}


Tablo 2'de görüldüğü gibi, katılımcıların öğrenci doyum ölçeğinden almış oldukları toplam puan ortalamasi 2,95 $\pm 0,63$ olup memnuniyetleri orta düzeydedir. Öğrencilerin doyum ölçeği öğretim elemanı alt boyutu puan ortalamas1 $(3,14 \pm 0,69)$ en yüksek düzeyde belirlenirken bilimsel sosyal etkinlikler alt boyutu puan ortalaması $(2,81 \pm 0,70)$ en düşük olarak belirlenmiştir (Tablo 2).

Tablo 3. Öğrencilerin Tanıtıcı Özellikleri, Bölüme ve Mesleğe İlişkin Görüşleri ve Eğitimden Beklentileri ile Doyum Ölçeği Puan Ortalamasının Karşılaştırılması

\begin{tabular}{|c|c|c|c|}
\hline Değişkenler & Ort. \pm SS & $\begin{array}{r}\text { Test } \\
\text { değeri }\end{array}$ & $\underset{\text { değgeri }}{p}$ \\
\hline \multicolumn{4}{|l|}{ Cinsiyet } \\
\hline Kadın & $2,96 \pm 0,60$ & $\mathrm{t}=-0,13$ & $\mathrm{p}=0,89$ \\
\hline Erkek & $2,95 \pm 0,71$ & & A.D. \\
\hline \multicolumn{4}{|l|}{ Yaş } \\
\hline 20 yaş ve altı & $2,98 \pm 0,58$ & $\mathrm{t}=0,86$ & $\mathrm{p}=0,39$ \\
\hline 21 yaş ve üstü & $2,93 \pm 0,67$ & & A.D. \\
\hline \multicolumn{4}{|c|}{ Ailede sağlık çalışanı varlığı } \\
\hline Evet & $2,92 \pm 0,72$ & $\mathrm{t}=-0,48$ & $\mathrm{p}=0,62$ \\
\hline Hayır & $2,96 \pm 0,61$ & & A.D. \\
\hline \multicolumn{4}{|l|}{ Sinıf } \\
\hline 2. sinif & $3,02 \pm 0,56$ & & \\
\hline 3. sinif & $2,78 \pm 0,68$ & $\mathrm{~F}=7,20$ & $\mathrm{p}=0,00^{*}$ \\
\hline 4. sinif & $3,07 \pm 0,63$ & & \\
\hline \multicolumn{4}{|c|}{ Bölümü isteyerek seçme } \\
\hline Evet & $3,04 \pm 0,52$ & $\mathrm{t}=2,51$ & $\mathrm{p}=0,01^{*}$ \\
\hline Hayır & $2,87 \pm 0,71$ & & \\
\hline \multicolumn{4}{|c|}{ Mesleği sevme düzeyi } \\
\hline 6 puan ve üzeri & $3,07 \pm 0,53$ & $\mathrm{t}=-4,12$ & $\mathrm{p}=0,00^{*}$ \\
\hline 5 puan ve alt 1 & $2,79 \pm 0,72$ & & \\
\hline \multicolumn{4}{|c|}{ Eğitimin mesleki beceri beklentisini karşılaması } \\
\hline Evet & $3,00 \pm 0,59$ & $t=2,69^{3}$ & $\mathrm{p}=0,00^{*}$ \\
\hline Hayır & $2,75 \pm 0,75$ & & \\
\hline \multicolumn{4}{|c|}{ Eğitimin bireysel gelișim beklentisini karșılaması } \\
\hline Evet & $3,00 \pm 0,61$ & $\mathrm{t}=2,84$ & $\mathrm{p}=0,00 *$ \\
\hline Hayır & $2,76 \pm 0,67$ & & \\
\hline
\end{tabular}

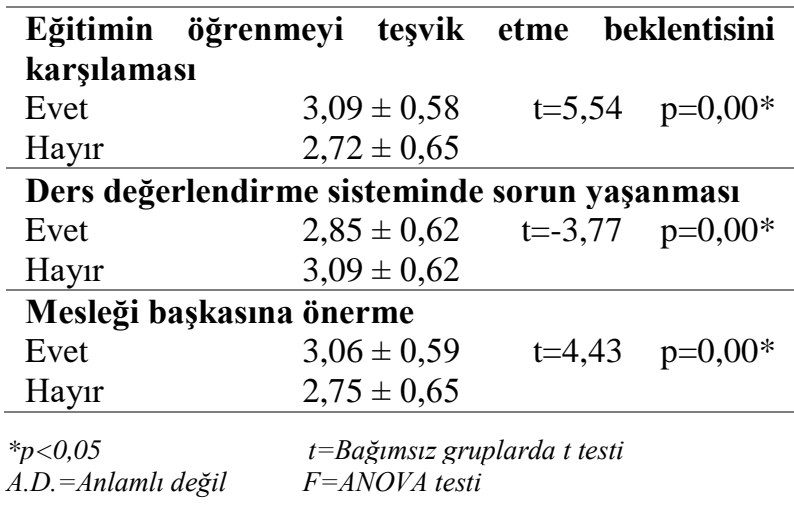


grupların puan ortalamaları açısından istatistiksel yönden anlamlı fark tespit edilmiş̧ir $(\mathrm{p}<0,05)$. Öğrencilerin hemşirelik mesleğini başkasına önerme durumlarına göre eğitimden memnuniyetleri kıyaslandığında; mesleği başkasına önerdiğini belirtenlerin memnuniyet düzeylerinin diğerlerinden yüksek olduğu saptanmış olup grupların puan ortalamaları arasında istatistiksel anlamll11k sağlanmıştır $(\mathrm{p}<0,05)$ (Tablo 3$)$.

Tablo 4. Öğrencilerin Yaşadıkları Sorunlar ve Çözüm Önerilerine İlişkin Görüşleri

\begin{tabular}{|c|c|c|c|}
\hline Sorunlar * & $\%$ & Öneriler* & $\%$ \\
\hline Klinik uygulamaya ilişkin sorunlar & & Klinik uygulamaya ilişkin öneriler & \\
\hline Soyunma odası ve dolapların yetersizliği & 53,2 & $\begin{array}{l}\text { Uygulama alanlarının sayı, nitelik ve } \\
\text { donanım yönünden uygun olması }\end{array}$ & 42,5 \\
\hline Hemşireler ve diğer ekip üyeleri ile iletişim sorunları & 38,6 & $\begin{array}{l}\text { Öğretim üyelerinin klinik uygulamalar } \\
\text { hakkında hemşireleri bilgilendirmesi }\end{array}$ & 43,3 \\
\hline $\begin{array}{l}\text { Entegre eğitim sisteminden dolayı tüm hastalıkların } \\
\text { bakımını öğrenemeden uygulamaya çıkılması }\end{array}$ & 52,6 & $\begin{array}{l}\text { Öğrencinin öğrendiklerine uygun beklenti } \\
\text { konulması }\end{array}$ & 38,1 \\
\hline Fiziksel özelliklere ilişkin sorunlar & & Fiziksel özelliklere ilişkin öneriler & \\
\hline Kampüste kütüphane olanaklarının yetersizliği & 75 & Kütüphane olanaklarının arttırılması & 70,4 \\
\hline $\begin{array}{l}\text { Spor faaliyetlerine yönelik yeterli alanların } \\
\text { olmaması }\end{array}$ & 65,5 & Uygun spor alanlarının oluşturulması & 53,4 \\
\hline Kantinin fiziki açıdan küçük olması & 64,9 & $\begin{array}{l}\text { Boş alanların oturma ve dinlenme alanı } \\
\text { olarak değerlendirilmesi }\end{array}$ & 59,7 \\
\hline Okul yönetimine ilişkin sorunlar & & Okul yönetimine ilişkin öneriler & \\
\hline $\begin{array}{l}\text { Öğretim elemanı başına düşen öğrenci sayısının } \\
\text { fazla olması }\end{array}$ & 62,5 & Öğrenci kontenjanlarının sınırlandırılması & 49 \\
\hline Kampüste fakülteler arası iletişimin sınırlı olması & 53,2 & $\begin{array}{l}\text { Kampüs öğrencilerinin kullanabileceği } \\
\text { ortak alanların oluşturulması }\end{array}$ & 51,8 \\
\hline Öğrencilerin burs, yurt ve ulaşım sorunları & 52,6 & $\begin{array}{l}\text { Öğrencilerin kendilerini ilgilendiren } \\
\text { kararlara katılımlarının sağlanması }\end{array}$ & 43,8 \\
\hline
\end{tabular}

*Birden fazla seçenek işaretlenmiştir.

Katılımciların

beklentilerinin karşılanmadığ 1 ve bu bağlamda sorun yaşadığı alanlara bakacak olursak; öğrenciler, klinik uygulamalara ilişkin "uygulama alanında soyunma odası ve dolap yetersizliğinden $(\% 53,2)$ ", sonrasında fiziksel özelliklere ilişkin "kütüphane olanaklarının yetersizliğinden (\%75)”, okul yönetimine ilişkin "öğrenci sayısının fazla olmasından $(\% 62,5)$ " kaynaklanan sorunları daha fazla yaşadıklarını belirtmiştir. Sorunlara karşılık katılımcıların en fazla önerdiği çözümler ise, klinik uygulamaya ait "öğretim üyelerinin klinik uygulamalar hakkında hemşireleri bilgilendirmesi (\%43,3)" ve "uygulama alanlarının sayı, nitelik ve donanım yönünden uygun olmasi $(\% 42,5)$ ", fiziki olanaklara ait kütüphane olanaklarının arttırılması $(\% 70,4)$, okul yönetimine ait "kampüs öğrencilerinin kullanabileceği ortak alanların oluşturulması $(\% 51,8)$ " şeklinde sıralanmaktadır (Tablo 4).
Ayrıca, öğrencilerin yarıdan fazlası $(\% 67,1)$ laboratuvar uygulamaları ile ilgili "uygulamaların az sayıda öğrenci gruplarıyla yapılmasını" önerirken çoğunluğu $(\% 76,2)$ kuramsal eğitim ile ilgili olarak "temel dersler ile seçmeli derslerin dengelenmesini” önermiştir.

Hemşirelik eğitiminde öğrencilerin mesleğe ve hemşireliğe karşı aldıkları tavır ve oluşturdukları yaklaşım oldukça önemlidir. $\mathrm{Bu}$ yaklaşımın kurulmasında eğitimden doyum almaları, beklentilerinin karşılanması etkin rol oynamaktadır. Hemşirelik öğrencilerinin memnuniyet düzeylerinin, beklentilerinin ve bunun karşıllğında yaşadıkları sorunlar ile çözüm önerilerinin incelendiği bu çalışma, gelecekte sağlık profesyonelleri arasında yer almasi olası olan profesyonellerin yetiştirilme sürecine önemli katkılarda bulunması açısından dikkat çekicidir. ABD' de 496 hemşirelik bölümü 
öğrencisiyle yapılan araştırmada öğrencilerin \%86's1 hemşirelik bölümünün zor olmasına rağmen aldıkları eğitiminden memnun olduklarını belirtmiştir. ${ }^{27}$ Buna karşılık, Espeland ve Indrehus (2003)'un çalışmasında, öğrencilerin \%70'inin hemşirelik eğitimine ilişkin programdan memnun olmadıkları belirlenmiş ve öğrencilerin klinik eğitimden daha memnun oldukları saptanmıştır. ${ }^{28} \mathrm{Bu}$ çalışmada ise, öğrenciler 10 üzerinden 5 puan ve alt1 değerlendirmede bulunarak öğrencilerin \%67,7'si teorik eğitimden, $\% 63,3$ 'ü uygulamalı eğitimden memnun olmadığını belirtmiştir. Bir başka çalışmada katılımcıların yarıya yakınının bölümdeki olanaklardan memnun olduklarını, kalan kısmının ise kararsız kaldıklarını ve memnun olmadıklarını ifade ettiği görülmüştür. ${ }^{29}$ Bölükbaş $(2018)^{30}$ 'ı yaptığ 1 çalışmada, öğrencilerin yarıya yakınının $(\% 41,1)$ iş bulma kolaylığı nedeniyle mesleği seçtiğini belirtmiş olup sonuç, bu çalışma sonucunu destekler niteliktedir. $\mathrm{Bu}$ çalışmada öğrencilerin önemli bir kısmı $(\% 60,8)$ hemşirelik mesleğini kolay iş bulma olanağı sağladığı için tercih ettiğini belirtirken bölümü isteyerek tercih etme oranlarının $(\% 48,8)$ bu düzeyde olmadığı gözlenmiştir. $\mathrm{Bu}$ durum öğrencinin ilgi duymadığı alanlara yönelmesine neden olmakta ve ilgi duymadığ bir alanda eğitim görmeleri üniversiteden aldığ 1 eğitimden memnuniyetini olumsuz yönde etkilemektedir. Ancak aldıkları eğitim ve bölümdeki yaşantıları sonucunda katılımcıların \%67,4'ü bu mesleği başkalarına önerebileceğini belirtmiş ve $\% 58,9$ 'u hemşirelik mesleğini sevme düzeyini 6 puan ve üzerinde değerlendirmiştir.

Eğitimin mesleki beceriye yönelik beklentiyi karşıladığını düşünenlerin memnuniyet düzeyleri $(3,00)$ diğerlerinden yüksek bulunmuştur. Yapılan bir başka çalışmada ise, öğrencilerin intern eğitim programı sonrasinda mesleki becerileri yönünden hedeflediklerinin üzerinde yeterliliğe sahip oldukları görülmüştür. ${ }^{31} \mathrm{Bu}$ verilerin sonucunda hemşirelik mesleğinin toplumdaki konumuna paralel olarak toplumumuzda ve özellikle üniversite çağı gençlerimizde meslekle ilgili belli önyargıların olduğu, öğrencilerin hemşirelik eğitimini tercih edip mesleği tanıdıklarında sevme düzeylerinde artış meydana geldiği ve bu mesleği başkalarına önermeye başladıkları anlaşılmaktadır. İyi yönde bir gelişim gözlenmekte olup bu durumun oluşmasında üniversitede verilen kaliteli eğitimin, intern programının ve öğrenciye sağladığı imkanların katkısı olduğu düşünülebilir.

Ölçek alt boyutlarında en yüksek puan ortalaması ögretim elemanı $(3,14)$ alt boyutuna ait iken en düşük puan ortalamasının bilimsel sosyal etkinlikler $(2,81)$ alt boyutuna ait olduğu saptanmıştır. Tüm ölçek ve ölçek alt boyutlarından alınan puanların "orta" düzeyde olduğu belirlenmiştir. Özdelikara ve Babur (2016)'un yaptığı çalışma sonucu bu çalışma sonucu ile paralellik göstermekte olup ölçek alt boyutlarından öğretim elemanı alt boyutu en yüksek puan ortalamasını alırken, bilimsel sosyal etkinlikler alt boyutu en düşük puan ortalamasını almıştır. Ancak sözü edilen çalışmada toplam ölçek ve ölçek alt boyutlarının puan ortalamaları "iyi" olarak saptanmıştır. ${ }^{32}$ Bir diğer araştırmada ise, en yüksek puanı eğitim öğretim niteliği faktörü almıştır. ${ }^{23}$ Kaynar ve ark.(2006)'nın yaptığı çalışmada öğrencilerin okul yönetim tarzı, kararlara katılım, öğretim elemanları, eğitimöğretim niteliği, sosyal kültürel olanaklar ve öğrencileri bilgilendirme faktörlerinin puan ortalamasının düşük olduğu belirlenmiştir. ${ }^{33}$ $\mathrm{Bu}$ çalışmada bilimsel sosyal etkinlikler alt boyutunun en az puan almasinın nedeni üniversitenin yeni binaya taşınması, fiziki yapı ve ulaşıma ilişkin sorunlar ile adaptasyon sürecinde olmasından kaynaklandığ 1 düşünülmektedir. Merkez yerleşkeden farklı bir alanda konumlandırılmasının öğrencilerin faaliyetlere katılımını zorlaştırdığ 1 ve bu durumun bilimsel sosyal etkinlikler alt boyutundan düşük puan alınmasına neden olduğu düşünülmektedir.

Çalışmaya katılan öğrencilerin sınıflarına göre doyum ölçeğinden almış oldukları puan ortalamaları kıyaslandığında; üçüncü sınıf öğrencileri ölçekten en düşük puan ortalamasını (2,78) alırken son sinıf öğrencilerinin en yüksek puan ortalamasını $(3,07)$ aldığı görülmüştür. Bu çalışmamızın sonuçlarını destekler nitelikte Özdelikara ve 
Babur (2016), Wildey ve ark. (2014)'nın çalışmalarında da ölçekten alınan düşük puan üçüncü sınıf öğrencilerine aittir. ${ }^{32,34}$ Diğer iki araştırmada ise, bu çalışmadan farklı olarak, ikinci sınıfların memnuniyet düzeyleri en yüksek bulunurken dördüncü sinıfların memnuniyet düzeyi en düşük bulunmuştur. ${ }^{35,36}$ Taştekin ve ark. (2016)'nın çalışmasında birinci ve üçüncü sınıf öğrencilerinin memnuniyet puanlarının ikinci ve son sınıf öğrencilerin puanlarına göre daha yüksek olduğu belirtilmiştir. ${ }^{37}$ İki hemşirelik okulunun karşılaştırıldığı çalışmada B kurumunda son sınıf öğrencilerinin ölçek puanlarının yüksek olduğu, A kurumunda ise üçüncü ve dördüncü sinıf öğrencilerin puanlarının düşük olduğu saptanmıştır. ${ }^{16}$ Çalışma sonuçlarına göre, üniversite yaşamının birinci yılında öğrenciler bölüme ve mesleğe uyum sağlamaya çalışırken duygusal anlamda gel-git yaşamakta ikinci y1lda adapte olan öğrenciler eğitimden memnun olurken üçüncü sinıfta derslerin ağırlaşması ve klinik uygulamalarının da etkisiyle memnuniyette düşme yaşandığı ön görülmektedir. Son sınıf öğrencilerinin ise intern programlarının olumlu etkisiyle mesleğe hazırlıklı olma ve eğitimden beklentilerini karşılama konusunda doyuma ulaştıklarından en yüksek memnuniyete sahip olduğu düşünülmektedir.

Hemşirelik eğitiminin birinci sınıftan itibaren klinik uygulama ile paralel ilerlediği düşünüldüğünde; uygulama sirasında karşılaşılan problemlerin farkına varılması ve sorunların ortadan kaldırılmasına yönelik çözüm önerilerinin geliştirilmesi öğrencilerin memnuniyet düzeyini olumlu yönde etkileyecektir. Norveç’te hemşirelik eğitiminin klinik uygulamalı derslerinde, eğitim kadrosu desteğinin yetersiz olması nedeniyle öğrencilerin özgüvenlerinin düşük olması yanında eğitime karşı isteksizlik yaşadıkları belirlenmiştir. ${ }^{28}$ Ülkemizde konuyla ilgili alan yazın incelendiğinde; öğrenciler eğitim kadrosunun sayısal yetersizliğinden, hemşirelerle yaşanan iletişim problemlerinden, soyunma ve toplant1 odalarının olmayışı veya yetersizliğinden, beslenme gereksinimlerinin yeterince karşılanmayışından, uygulama alanlarının yetersizliğinden, uygulamalarda öğrenci sayısının fazlalığından ve kuramsal eğitimi uygulamaya aktarmada yaşanan sorunlar konularından yakınmışlardır. Öğrenci hemşireler klinik alanda yaşadığı sorunları çözmede hemşirelerden yeterli destek alamadığını ve öğrencilerin profesyonel olarak gelişimlerine yardımcı olamadıklarını belirtmişlerdir. ${ }^{38}$ Kahraman ve Kılıç (2021)'in çalışmasında okul yaşamından memnun olan öğrencilerin mesleki benlik saygısı da yüksek bulunmuştur. ${ }^{39} \mathrm{Bu}$ nedenle üniversitelerin mesleki sorumluluk, otonomi, profesyonellik çerçevesinde ve mesleğine saygı, sevgi duyan, mesleki ve bireysel gelişime sahip üyeler yetiştirmek için memnuniyeti ön plana almaları gerektiği düşünülmektedir.

Yine, Dönmez ve Karaöz Weller (2019)'in yaptıkları çalışmada klinik uygulamaya yönelik sorunlar olarak "aynı klinikte öğrenci hemşire sayısı fazlalığı (\%55,5)", "hemşirelerin öğrencilere yönelik tutumları $(\% 59,5)$ " ve "öğrencinin iş yükü azaltan eleman olarak görülmesi $(\% 73,5)$ " bulunurken öneri olarak "uygun fiziki ortam sağlanması $(\% 47,5)$ ", "okul-klinik iş birliği $(\% 74,5)$ ", "öğretim elemanlarının klinikte daha çok bulunması $(\% 60,0)$ " belirtilmiştir. ${ }^{40}$ Çalışma sonuçları bu çalışma sonuçlarını destekler nitelikte olup öğrencilerin üçte birinden fazlası $(\% 38,6)$, "klinik uygulama alanlarında hemşireler ve diğer ekip üyeleri ile iletişim sorunları yaşadığından" yarıdan fazlası $(\% 62,5)$, “öğrenci sayısının fazla olmasından dolayı öğretim elemanından yeterince yararlanamadığından" yakınmıştır. $\mathrm{Bu}$ sorunların çözümüne yönelik olarak, öğrencilerin yarıya yakını $(\% 43,3)$ klinik uygulamalarda öğrencilerden neler beklenmesi gerektiği konusunda öğretim elemanlarının hemşireleri bilgilendirmesini, fiziki olanakların iyileştirilmesini $(\% 42,5)$ önermiştir.

Son yıllarda üniversitelerin hemşirelik bölümündeki kontenjanların artması ve klinik uygulama alanlarına öğrencilerin dağıtımında il düzeyinde merkeziyetçi yaklaşımın olmasıyla birlikte okul yönetimlerinin sıkıntı yaşadığı, hemşirelik eğitiminin gerek kuramsal gerekse uygulama boyutlarında 
daha farklı ve daha ciddi sorunlarla karşılaşıldığ1 ve bu durumun yönetim ve eğitim kadrosu ile öğrencilerin memnuniyetlerini olumsuz yönde etkilediği söylenebilir.

\section{SONUÇ VE ÖNERÍLER}

Hemşirelik öğrencilerinin eğitimden memnuniyetlerinin "orta" seviyede olduğu ve üniversitede verilen mesleki eğitimin öğrenmeyi teşvik ettiği, beceri ve bireysel gelişime katkı sağladığı belirlenmiştir. Üniversitelerin verdiği mesleki eğitimlerin yanı sıra sağladığı olanaklar da öğrencilerin memnuniyet düzeylerini etkilemektedir. $\mathrm{Bu}$ nedenle kampüs içinde ve dişında bilimsel sosyal faaliyetlerin arttırılması ve öğrencilerin katılım için teşvik edilmesi önerilmektedir. Doyumları diğer sınıflara göre düşük seviyede belirlenen üçüncü sınıf öğrencilerinin doyumlarını arttırmaya ve beklentilerini karşılamaya yönelik düzenleme çalışmaları yapılması önerilmektedir. Uygulama alanında soyunma odası ve dolap yetersizliği, kantin, kütüphane ve sportif olanakların yetersizliği ve kontenjanların fazla olması ögrencilerin memnuniyet düzeyini önemli ölçüde etkileyen faktörler olup kurumların fiziki yeterliliklerine göre öğrenci alımını değerlendirmesi önerilmektedir. Ayrıca öğretim elemanları ile hemşirelerin paylaşıma açık, motive edici ve destekleyici tutum geliştirmesiyle birlikte iyi bir rol model olmas1, klinik alanlarda rehber hemşire sisteminin oluşturulması, öğrenci odaklı, sorunlara duyarlı, erişilebilir ve demokratik yaklaşımlı kurum kültürünün benimsenmesi önerilmektedir.

Nitelikli ve profesyonel hemşireler yetiştirmek için teorik eğitimin yanında klinik uygulama alanlarının sayı, nitelik ve donanım açısından yeterli hale getirilmesinin ve klinik uygulamaya destek veren hemşire grubunun derslerin uygulamalı eğitimi ile ilgili beklentilere ilişkin bilgilendirilmesinin önemi vurgulanmış olup sonuçların kalite çalışmaları için yol gösterici olacağı düşünülmektedir.

\section{KAYNAKLAR}

1. Topuksak, B. ve Kubilay, G. (2010). "Hemşirelik Eğitiminde Kalite: Toplum Sağlığı Açısından Önemi”. Maltepe Üniversitesi Hemșirelik Bilim ve Sanatı Dergisi, Sempozyum Özel Sayıs1, 307-311.

2. Bayık, A. (2004). "Hemșirelik Araștırmalarına Kalite Yaklaşımı”. 8-10 Nisan 2004 II. Ulusal Hemşirelikte Araştırma Sempozyumu (61-79), Ankara.

3. Celikkalp, Ü, Aydın, A. ve Temel, M. (2010). "Bir Sağlık Yüksekokulu Hemşirelik Bölümü Öğrencilerinin Aldıkları Eğitime İlişkin Görüşleri”. Maltepe Üniversitesi Hemşirelik Bilim ve Sanatı Dergisi, 3 (2), 2-14

4. Öztürk, N, Orgun, F. ve Akçakoca, B. (2018). “Türkiye’de Hemșirelik Eğitimi Veren Yükseköğretim Kurumlarına İlișkin Güncel Durumun İncelenmesi”. Yüksek Öğretim Dergisi, 8 (2), 150-157.

5. Kaya, H, Taşocak, G, Akçin, E. ve Kısa, B. (2003). "Hemşirelik Yüksekokulu Son Sınıf Öğrencilerinin Yüksekokulun Genel Hedeflerine Ulaşma Durumlarına İlişkin Görüşleri”. Florence Nightingale Hemşirelik Dergisi, 13 (54), 77-84.

6. Kılıç Akça, N. ve Taşçı, S. (2011). "Hemşirelik Eğitimi ve Eleștirel Düșünme”. Mersin Üniversitesi Eğitim Fakültesi Dergisi, 5 (2), 187-196.

7. Ansarı, W.E. and Stock, C. (2010). "Is The Health and Wellbeing of University Students Associated With Their Academic Performance? Cross Sectional Findings From The United Kingdom. International". Journal of Environmental Research and Public Health, 7 (2), 509-527.

8. Kaya, İ. ve Engin, O. (2004). "Yüksek Öğretim Kurumu İçerisinde Yer Alan Bir Bölümde Kalite İyileștirme Sürecine
Yönelik Olarak Öğrenci Memnuniyetinin Ölçülmesi". Mühendislik ve Fen Bilimleri Dergisi, 4, 218-228.

9. Egelioğlu, N, Arslan, S. ve Bakan, G. (2011). "Hemşirelik Öğrencilerinin Memnuniyet Durumlarının Akademik Başarıları Üzerine Etkisi”. Hemșirelik Araştırma Geliștirme Dergisi, 13 (1), 4-24.

10. Munteanu, C, Ceobanu, C, Bobâlcă, C. and Anton, O. (2010). "An Analysis of Customer Satisfaction in a Higher Education Context". International Journal of Public Sector Management, 23 (2), 124-140

11. Dhaqane, M.K. and Afrah, N.A. (2016). "Satisfaction of Students and Academic Performance in Benadir University". Journal of Education and Practice, 7 (24), 59-63.

12. Ansari, W.E. (2002). "Student Nurse Satisfaction Levels With Their Courses: Part I Effects of Demographic Variblaes". Nursing Education Today, 22 (2), 159-169.

13. Ekinci, C.E. ve Burgaz, B. (2007). "Hacettepe Üniversitesi Öğrencilerinin Bazı Akademik Hizmetlere İlişkin Beklenti ve Memnuniyet Düzeyleri”. Hacettepe Üniversitesi Eğitim Fakültesi Dergisi, 33 (33), 120-134.

14. Uzgören, N. ve Uzgören, E. (2007). "Dumlupınar Üniversites Lisans Öğrencilerinin Memnuniyetini Etkileyen Bireysel Özelliklerin İstatistiksel Analizi-Hipotez Testi, Ki-Kare Testi ve Doğrusal Olasılık Modeli”. Dumlupınar Üniversitesi Sosyal Bilimler Dergisi, 17, 173-193.

15. Önem, E, Polat, M, Nayır, T. ve Eroğlu, F. (2009). "Süleyman Demirel Üniversitesi Isparta Sağlık Hizmetleri Meslek Yüksek Okulu Öğrencilerinin Genel Memnuniyet Düzeylerinin Belirlenmesi”. Süleyman Demirel Üniversitesi Yaşam Dergisi, 1 (1), 4-6. 
16. Baykal, Ü, Harmanc1, A.K, Eşkin, F, Altuntaş, S. ve Sökmen S. (2011). "Öğrenci Doyum Ölçeği-Kısa Form GeçerlikGüvenirlik Çalışması”. Anadolu Hemşirelik ve Sağlık Bilimleri Dergisi, 14 (4), 60-68.

17. Dilşeker, F. (2011). Devlet ve Vakıf Üniversitelerinde Hizmet Kalitesi, Öğrenci Memnuniyeti, İmaj, Sadakat ve Tavsiye Etme Arasındaki İlişkinin İncelenmesi. Yüksek Lisans Tezi, Uşak Üniversitesi Sosyal Bilimler Enstitüsü, Uşak.

18. Koç, K. (2019). Sağlık Bilimleri Fakültesi Öğrencilerinin Okuldan Memnuniyet Düzeyleri ve Akademik Başarı Puanları Arasındaki İlişkinin İncelenmesi. Yüksek Lisans Tezi, Balıkesir Üniversitesi Sağlık Bilimleri Enstitüsü, Balıkesir.

19. Elliot, K.M. and Shin, D. (2002). "Student Satisfaction: An Alternative Approach to Assessing this Important Concept". Journal of Higher Education Policy and Management, 24 (2), 97-109.

20. Tsarenko, Y. and Mavonda, F.T. (2001). "Resources and Capabilities Determinants of Student Satisfaction Do Foreıgn and Local Students Differ". In Proceedings of the Conferance ANZMA (1-5), Auckland.

21. Elliott, K.M. (2002). "Key Determinants of Studen Satisfaction". Journal of College Student Retention: Research, Theory \& Practice, 4 (3), 271-279.

22. Chiandotto, B, Bini, M. and Bertaccini, B. (2007). "Quality Assessment of The University Educational Process: An Application of The ECSI model". In Effectiveness of University Education in Italy, Physica-Verlag HD, 43-54.

23. Yangın, H. ve Kırca, N. (2013). "Antalya Hemșirelik Öğrencilerinin Memnuniyet Düzeyleri ve Etkileyen Faktörler" Gümüşhane Üniversitesi Sağlık Bilimleri Dergisi, 2 (1), 78-94.

24. Karadağ, E. ve Yücel, C. (2020). "Türkiye Üniversite Memnuniyet Araştırması 2020”. Erişim adresi https://f903aba4-e11a-4804-93a8 aa17928bdbe0.filesusr.com/ugd/779fe1_673141f15a3c480d9a 3266a0c4cb1067.pdf (Erișim tarihi:21.03.2021)

25. Seren İntepeler, S. (2014). Kalite Yönetimi. In: Editör Ü. BAYKAL, E. ERCAN TÜRKMEN (Ed.). Hemşirelik Hizmetleri Yönetimi (308-309). İstanbul: Akademi Basın.

26. Söylemez, D, Sur, H. ve Cebeci, D. (2005). "Hemşirelerin İs Doyumu İle İlgili Bir Meta Analiz Çalışması”. Hastane Yönetimi Dergisi, Nisan-Mayıs-Haziran, 34-41.

27. Norman, L, Buerhaus, P.I, Donelan, K, Mccloskey, B. and Dittus, R. (2005). "Nursing Students Assess Nursing Education". Journal of Professional Nursing, 21 (3), 150-158.

28. Espeland, V. and Indrehus, O. (2003). "Evaluation of Students, Satisfaction With Nursing Education in Norway". Journal of Advanced Nursing, 42 (3), 226-236.

29. Şahin, İ, Zoraloğlu, Y.R. ve Fırat, N.Ş. (2011). "Üniversite Öğrencilerinin Yaşam Amaçları, Eğitsel Hedefleri Üniversite
Öğreniminden Beklentileri ve Memnuniyet Durumları”. Kuram ve Uygulamada Eğitim Yönetimi, 3 (3), 429-452.

30. Bölükbaş, N. (2018). "Hemşirelik Öğrencilerinin Meslek Seçimi ve Etkileyen Faktörler”. Ordu Üniversitesi Hemșirelik Çalışmaları Dergisi, 1 (1), 10-17.

31. Tosun, N, Oflaz, F, Akyüz A, Kaya, T, Yava A, Yıldız, D. ve Akbayrak, N. (2008). "Hemșirelik Yüksek Okulu Öğrencilerinin İntörn Eğitim Programından Beklentileri İle Program Sonunda Kazanım ve Önerilerinin Değerlendirilmesi”. Gülhane Tıp Dergisi, 50 (3), 164-171.

32. Özdelikara, A. ve Babur, S. (2016). "Hemşirelik Öğrencilerinin Öğrenimlerine İliskin Doyum Düzeyi ve Etkileyen Faktörler". Dokuz Eylül Üniversitesi Hemşirelik Fakültesi Elektronik Dergisi, 9 (1), 2-8

33. Kaynar, A, Sahin, A, Bayrak, D, Karakoc, G, Ülke, F. ve Öztürk H. (2006). "Karadeniz Teknik Üniversitesi Trabzon Sağlık Yüksekokulu Hemșirelik Öğrencilerinin Doyum Düzeyleri". Cumhuriyet Üniversitesi Hemşirelik Yüksekokulu Dergisi, 10 (3), 12-19.

34. Wildey, K.M, Kenny, P, Parmenter, G. and Hall, J. (2014). "Educational Preparation For Clinical Nursing: The Satisfaction of Students and New Graduates From Two Australian Universities". Nurse Education Today, 34 (4), 648654.

35. Ulusoy, H, Arslan, A, Öztürk, N. ve Bekar, M. (2010) "Hemşirelik Öğrencilerinin Eğitimleriyle İlgili Memnuniyet Düzeylerinin Saptanması". Maltepe Üniversitesi Hemşirelik Bilim ve Sanat Dergisi, 3 (2), 15-24

36. Bülbül, T, Ateş, D. ve Öztürk, S. (2017). "Sağlık Bilimleri Fakültesi Hemsirelik Bölümü Öğrencilerinin Lisans Düzeyinde Aldıkları Hemşirelik Eğitimi ile İlgili Memnuniyetlerinin Belirlenmesi”. Sağlık Bilimleri Dergisi, 26 (2), 133-139.

37. Taştekin, A, Türkdönmez, B, Güler, M, Yılmaz, A. ve Erşahan, T. (2016). "Hemşirelik Öğrencilerinin Klinik Ortamdaki Doyum Düzeyleri ve Etkileyen Faktörler". Florence Nightingale Hemşirelik Dergisi, 24 (1), 24-29.

38. Karadağ, G, Parlar Kılıç, S, Ovayolu, N, Ovayolu, Ö. ve Kayaaslan, H. (2013). "Öğrenci Hemsirelerin Klinik Uygulamada Karşılaştıkları Güçlükler ve Klinik Hemşireler Hakkındaki Görüşleri”. TSK Koruyucu Hekimlik Bülteni, 12 (6), 665-672.

39. Kahraman, İ. ve Fırat Kılıç, H. (2021). "Hemşirelik Öğrencilerinin Mesleki Benlik Saygısı ve Etkileyen Faktörler". Adnan Menderes Üniversitesi Sağlık Bilimleri Fakültesi Dergisi, 5(1), 1-12.

40. Dönmez, S. ve Karaöz Weller, B. (2019). "Hemşirelik Son Sinıf Öğrencilerinin Aldıkları Eğitime İlişkin Görüşlerinin İncelenmesi”. Acıbadem Üniversitesi Sağlık Bilimleri Dergisi, 10 (1), 42-48. 